\title{
Striking for Freedom: The 1831 Uprising at Golden Grove Plantation, Cat Island
}

\section{Allan D. Meyers Eckerd College ${ }^{1}$}

\begin{abstract}
Although the study of colonial Bahamian slave resistance has advanced in recent decades, key episodes of insurrection have yet to be fully explored. Recent investigation of primary source materials related to an 1831 uprising at Golden Grove, Joseph Hunter's plantation at Cat Island, suggests that its causes and consequences were more complex than have hitherto been acknowledged. Juxtaposition of an official narrative, espoused by slave owners, with a counternarrative, adopted by at least some slaves, emphasizes historical multi-vocality. Details of the case, which reached London at a time of accelerating abolitionism, underscore several broader themes in the history of West Indian slavery. These include the pervasive nature of resistance, the place of amelioration laws in stimulating rebellion, and the role of authoritative slaves in mobilizing others for collective action akin to labor strikes. The degree to which scholars stress confrontational resistance at Cat Island and other Bahamian locations has important implications for contemporary political discourse.
\end{abstract}

\section{INTRODUCTION}

"Slavery," in the words of Michael Craton, "distorts the personality and all human relationships, so that only in resistance can the self be realized and dignity restored" (1979, p. 125). The last four decades have witnessed significant advances in our understanding of slave resistance on colonial Bahamian plantations (Craton, 1983; Craton \& Saunders, 1990; Saunders, 1984). Daily resistance such as foot-dragging, feigned illness, and sabotage involved actions that undermined the efficiency of the estate. Those seeking escape from the dehumanizing effects of enslavement often absconded, and fugitive slaves were a constant concern of the planter class. Less frequently, resistance erupted into open rebellion. The 1830 insurrection at Exuma, known widely as "Pompey’s Revolt," is perhaps best known (Craton, 1983). There were, however, other insurrections with strong reverberations. Among them was an 1831 uprising at Golden Grove, the plantation of Joseph Hunter at Cat Island. Saunders (1978, pp. 432-433) brought this episode to light, and scholars have occasionally invoked it since then (Brown, 1992, pp. 79-80; Craton \& Saunders, 1992, p. 387; Lofquist, 2010, p. 25).

\footnotetext{
${ }^{1}$ A. D. Meyers, Professor of Anthropology, Eckerd College, St. Petersburg, FL 33711

Acknowledgements: Archival research was supported by an L. W. Chapin Faculty Fellowship at Eckerd College. Special thanks to the staff of the Bahamas Archives for assistance with primary source materials, as well as to the IJBS reviewers who commented on earlier versions of the manuscript.

E-mail: meyersad@eckerd.edu

APA reference: Meyers, A. D. (2015). Striking for freedom: The 1831 uprising at Golden Grove Plantation, Cat Island. The International Journal of Bahamian Studies, 21(1), 74-90. http://dx.doi.org/10.15362/ijbs.v21i1.246
} 
Despite acknowledgements of Golden Grove's historical conflict, a complete understanding of its causes, details, and consequences is still wanting. There has long been uncertainty about the number of people involved, as well as their roles on the estate and their social identities (Saunders, 1985, p. 189). Moreover, no published source has considered how officials in London interpreted the case. As a consequence of this incomplete picture, an important work on colonial Bahamian race relations reduces the episode at Golden Grove to a personal disagreement between slave and slaveholder. Johnson contends that:

... the disturbances on the Joseph Hunter plantation [together with disturbances on some other Bahamian estates] ... do not fall under the rubric of either a rebellion or a revolt. There were no deaths, nor property destruction, and the causes were usually not deliberate attempts to defy authority (2000, pp. 165-166).

By overlooking the full extent of collective and conscientious resistance, such an assessment diminishes the Hunter slaves' struggle for dignity.

The Cat Island Heritage Project, an investigation of Loyalist-era plantation sites authorized by the Antiquities, Monuments, and Museums Corporation of The Bahamas, has prompted a fresh examination of archival materials related to the Golden Grove uprising. In particular, judicial records held by the Bahamas Archives suggest that the confrontation was not simply an interpersonal dispute. It involved upwards of 50 people, both male and female. Its leaders were classified as "creoles," persons born in the Americas rather than in Africa. Moreover, its causes were multifaceted. They included both an official narrative embraced by slave owners and a counter-narrative embraced by at least some of the slaves. In either case, the uprising signified the Hunter slaves' unwillingness to comply with plantation order on the master's terms (Craton, 1979, p. 124), and it should be considered among other slave revolts.

The Golden Grove uprising highlights several themes in the study of West Indian slavery (Craton, 1979, pp. 113-118. Resistance to slavery was endemic, and the legislative successes of the abolition lobby in Britain influenced the expectations of slaves who often saw these enactments as heralding full emancipation. Statutes in the 1820s designed to improve the situation of slaves ultimately stimulated more open resistance. When insurrection was ignited, slaves in authoritative positions often expressed solidarity with lower-ranking slaves and spurred them into action. Furthermore, slave leaders implemented labor-strike strategies designed to destabilize plantation operations. The intent was not to be revolutionary in the sense of wanting to overthrow the entire political and economic system.

\section{The Hunter Family at Cat Island}

Joseph Hunter was an attorney, judge, and politician who held appointments on His Majesty's Council for the Bahamas from 1808 until the mid-1830s (Blue Book, 1834, p. 59, 1838, pp. 58-59). He even served as the Colony's interim governor upon the departure of Governor William Colebrooke in 1837 (Great Britain Foreign Office, 1838, pp. 134135). With his wife, Elizabeth, he maintained a residence in Nassau where they were members of Christ Church Anglican Parish (Estate Appraisals, 1838). In 1801, Hunter partnered with John Russell, a Loyalist shipbuilder from East Florida, to acquire 700 acres adjacent to Andrew Deveaux, senior's plantation at the south-eastern end of Cat Island (Bahama Records, 1801). A 400-acre tract, presumably a portion of the original 700 acres, was surveyed solely for Hunter in 1806, and a deed for that tract was finalized in early 
1808 (Bahama Records, 1808; Land Grants, 1810). Although Hunter held land on other Bahamian islands (Land Grants, 1813), his principal investment was the 400 acres that became Golden Grove (Figure 1). At the apex of a hill, nearly three miles north of Port Howe, Hunter had a large house constructed.
It was built on a slope so that the northern face was one story and the southern face was two stories. The house boasted 13 rooms and 2350 square feet of interior space. Whatever his involvement with Nassauvian politics and social life, records after 1820 consistently identified Hunter as a Cat Island resident.

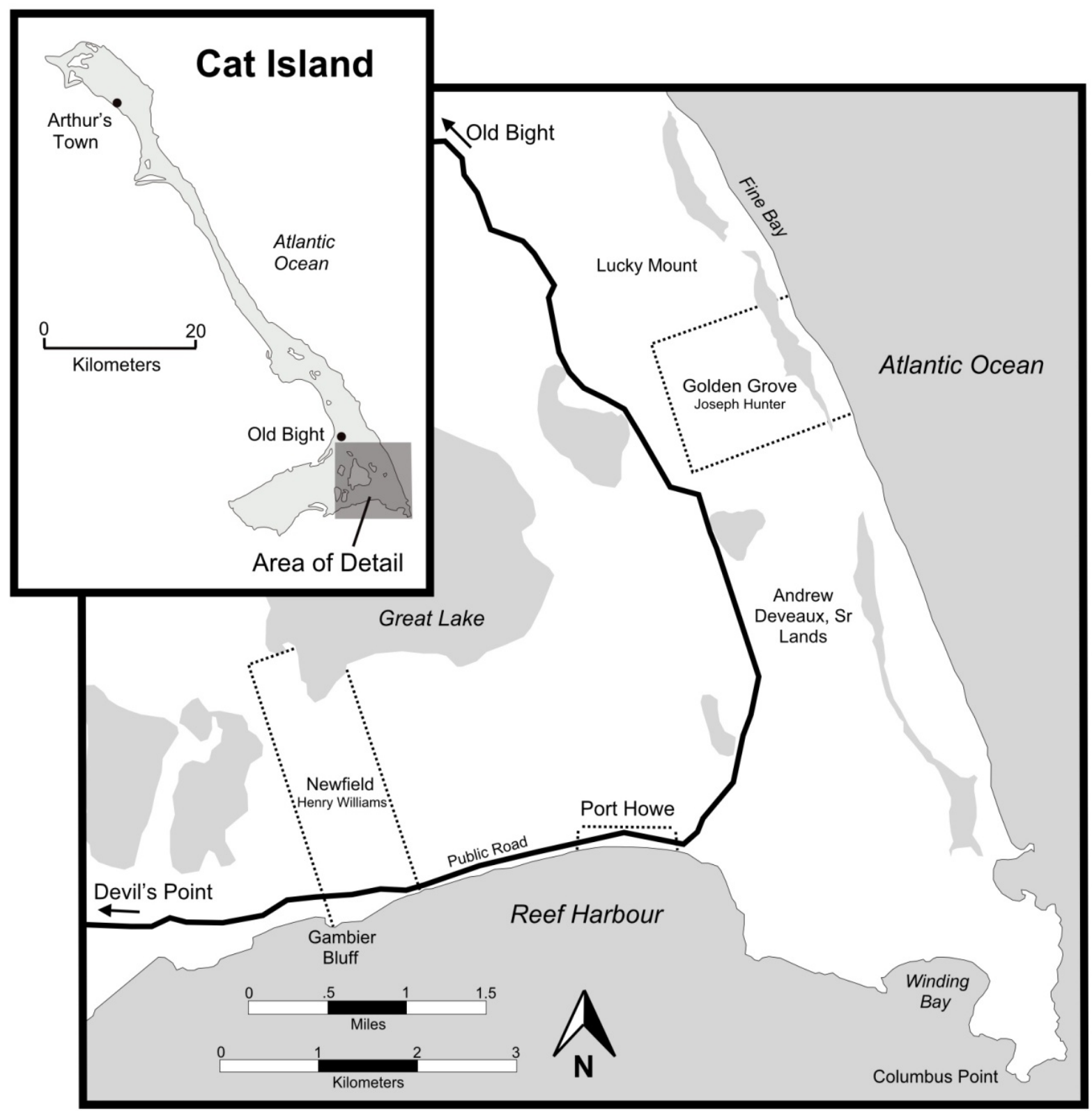

Figure 1. Location of Joseph Hunter's 400-acre tract at the south-eastern end of Cat Island, showing its relation to the Newfield plantation and other properties discussed in the text. 
Like other Bahamian planters, Hunter initially cultivated cotton (Royal Gazette, 1808b; Saunders, 2002). By the time of the slave uprising, cotton had been supplanted by a more diversified strategy focused on cattle, sheep, and subsistence crops (Estate Appraisals, 1838). The shift from unsustainable cotton monoculture to a provision-oriented plantation was part of larger economic processes in the Bahamas in the early nineteenth century. Laws passed in 1811 and 1813 created incentives for Bahamian planters to produce crops like Indian corn or Guinea corn beyond the subsistence needs of the estate so that any excess crops could be channeled into New Providence markets (H. Johnson, 1996, p. 29).

Joseph and Elizabeth Hunter had two children, Hugh Edward and Sarah Anne. Their son became a member of the Grenadier Guards, a famed infantry regiment of the British Army. Their daughter married Charles L. Poitier, a Jamaica-born captain in the Seventh West India Regiment who became the Collector of Customs in Nassau (Royal Gazette, 1808a). According to his will, which was drafted at Golden Grove in December 1822, Poitier had amassed "upwards of three thousand acres" near the Bight on Cat Island (Supreme Court Wills, 1822). The will also mentioned land purchased from John Russell, possibly the tract adjacent to Golden Grove that became known as Lucky Mount. Charles Poitier died prior to 1828, leaving his properties in the hands of his wife, Joseph Hunter's daughter, then a mother of young children. Sarah Anne Poitier maintained a house in Nassau, as well as plantation lands on Cat Island, for the remainder of her life. She stayed with her father at Golden Grove for stretches of time, including the second half of 1831 when the slave uprising occurred.

\section{The Slave Community at Golden Grove in 1831}

Sir James Carmichael Smyth (1832b), the
London-born governor of the Bahamas, reckoned in 1832 that "Mr. Hunter lives at the Island of St. Salvador [Cat Island] surrounded by about three hundred slaves without a single white man or a free man of any description." The estimate of 300 slaves would have placed Hunter near the top of a list of Bahamian slaveholders in the 1830s (Craton \& Saunders, 1992, Table 11). Triennial slave registration returns suggest that, while Hunter's slaveholding was indeed considerable, the situation was more complex than Smyth's comment might lead one to believe. Hunter reported 115 slaves at Golden Grove at the beginning of 1831, a number that would grow to 120 on the eve of emancipation (Register of Slaves, 1831d, 1834a). These figures made Hunter the largest owner of Cat Island slaves and one of the top slaveholders in the colony in that decade (Craton \& Saunders 1992, p. 280).

As it turned out, the second largest holder of Cat Island slaves in the 1830s was Hunter's widowed daughter, Sarah Anne Poitier. As dowager of Charles Poitier's estate, she had access to 142 slaves in 1831. Ninety-eight of these lived on Cat Island, while nearly all others lived on New Providence. The Hunter family, father and daughter combined, thus held 213 slaves on Cat Island in the months before the uprising (Table 1). This is likely the population to which Governor Smyth was referring because court testimony showed that some, if not all, of the Poitier slaves on Cat Island lived in the vicinity of Golden Grove (General Court, 1832). They nevertheless occupied a tract that was apart from her father's property, quite possibly the old Russell acreage called Lucky Mount. Although technically on separate lands, the governor presumably understood both groups of slaves to have been managed jointly. In the end, the Hunters owned perhaps a third of all slaves on Cat Island in the run-up to emancipation. 
Table 1.

Selected Slave Holdings at Cat Island in 1831

\begin{tabular}{l|c|cc|cc|cc}
\hline Slave Return & Total Slaves & Male & Female & Creole & African & Black & Mulatto \\
\hline Joseph Hunter & $115^{1}$ & $46(40 \%)$ & $69(60 \%)$ & $100(87 \%)$ & $15(13 \%)$ & $105(91 \%)$ & $10(9 \%)$ \\
Estate of Charles Poitier* & $86^{2}$ & $39(45 \%)$ & $47(55 \%)$ & $72(84 \%)$ & $14(16 \%)$ & $83(97 \%)$ & $3(3 \%)$ \\
Estate of C. Poitier \& J. G. & $12^{3}$ & $5(42 \%)$ & $7(58 \%)$ & $7(58 \%)$ & $5(42 \%)$ & $12(100 \%)$ & $0(0 \%)$ \\
Hunter & & & & & & & \\
Hunter/Poitier Combined & 213 & $90(42 \%)$ & $123(58 \%)$ & $179(84 \%)$ & $34(16 \%)$ & $200(94 \%)$ & $13(6 \%)$ \\
Henry M. Williams & $62^{4}$ & $30(48 \%)$ & $32(52 \%)$ & $54(87 \%)$ & $8(13 \%)$ & $58(94 \%)$ & $4(6 \%)$ \\
\hline
\end{tabular}

1 Excludes two persons on New Providence (Register of Slaves, 1831d).

2 Excludes 43 persons on New Providence and one at Ragged Island (Register of Slaves, 1831a).

3 Excludes 16 persons on New Providence (Register of Slaves, 1831b).

4 See Register of Slaves, 1831c.

${ }^{*}$ Administered by Sarah Anne Poitier

Joseph Hunter's estate population was drawn, in part, from the cotton plantation of Andrew Deveaux, senior, the father of Colonel Andrew Deveaux who organized the expedition of Loyalists in 1783 that reclaimed the Bahamas from the Spanish (Bahama Gazette, 1815; Craton, 1993). At the time of his death in 1814, the elder Deveaux possessed 100 slaves (Estate Appraisals, 1815). Hunter acquired some of these people, most notably the family of "Black Dick," one of two work-gang supervisors, or "drivers," on the Deveaux estate. The driver, as noted by Craton (1982, p. 54), was an indispensable part of plantation organization, serving as liaison between master and other slaves. Dick was around 28 years old at the time he moved to nearby Golden Grove with his wife and six children. Another child would be born around 1820 on the Hunter plantation where Dick continued in the position of driver and carried the Deveaux surname, as was often the practice for slaves sold away from their first owners. He and his sons, Wally and Richard, would assume central roles in the uprising.

The 1831 population at the Hunter estate was divided into at least 17 family groups. The community's demographics were characterized by gender imbalance, with only 67 males for every 100 females (Figure 2).

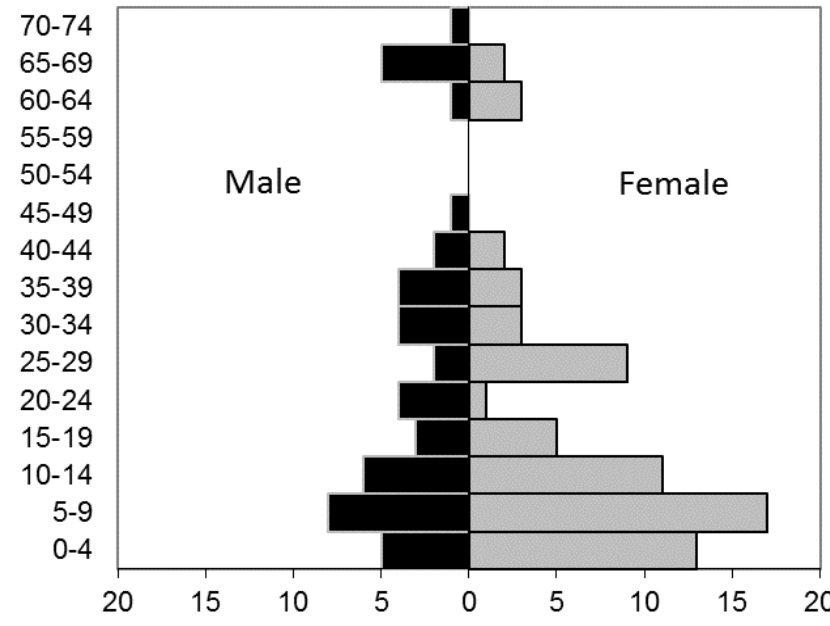

Figure 2. Population pyramid for the Golden Grove community in 1831, showing age groupings in years along the vertical axis. Bars represent the total number of males and females in each age category.

The community was also youthful, with children under 13 years constituting nearly $50 \%$ of the population. If the five deaths that Hunter reported for the period 1825-1827 were representative, the average age at death at Golden Grove was about 43. Yet, some slaves attained even greater longevity. In 1831, 12 people were registered as being 60 years or older, many of them African by birth. Overall, only $13 \%$ had originated in Africa. Like other Bahamian plantations of the era, Golden Grove was a largely creole community. The division of labor at Golden 
Grove can be gleaned from the last slave registration before emancipation; it was the only time when occupations were systematically recorded (Register of Slaves, 1834a). Among the 93 able-bodied slaves of working age at that time, more than half were field laborers (Figure 3). One-fifth of slaves, all males, managed livestock, while one-sixth of the population, mostly children, carried water and weeded pasture. Roughly 7\% worked in a domestic capacity, including basket makers, laundresses, and house servants. Mulattoes, persons of mixed African and European ancestry, did not seem to enjoy occupational privileges such as working as house servants. Only one mulatto domestic, a seamstress, appeared in the 1834 register. The few other mulattoes worked in the fields.

\section{Official Record of the Uprising}

Legal records, official correspondence, and contemporary newspapers provide a detailed, albeit a decidedly one-sided, account of the uprising. Transcripts of court proceedings that followed the turmoil are the principal historical source (General Court, 1832). Court records indicate that tensions were visibly mounting on Hunter's estate as much as a week before the outbreak of violence. Superficially, the conflict was sparked by disagreement over a provision of the Consolidated Slave Act of 1797. The law stipulated that slaves were entitled to Christmas day and the two following working days as holidays (Johnson, 2000, p. 49; Saunders, 1985, p. 173). The longstanding custom of slaves having Sundays to themselves (this became official in 1830) meant that slaves often had four total days without labor during Christmas week (Craton \& Saunders, 1992, p. 231). In 1831, however, Christmas fell on a Sunday. This meant that slaves would be deprived of one of their accustomed 'free' days. In such cases, masters were at their discretion in managing the circumstances.

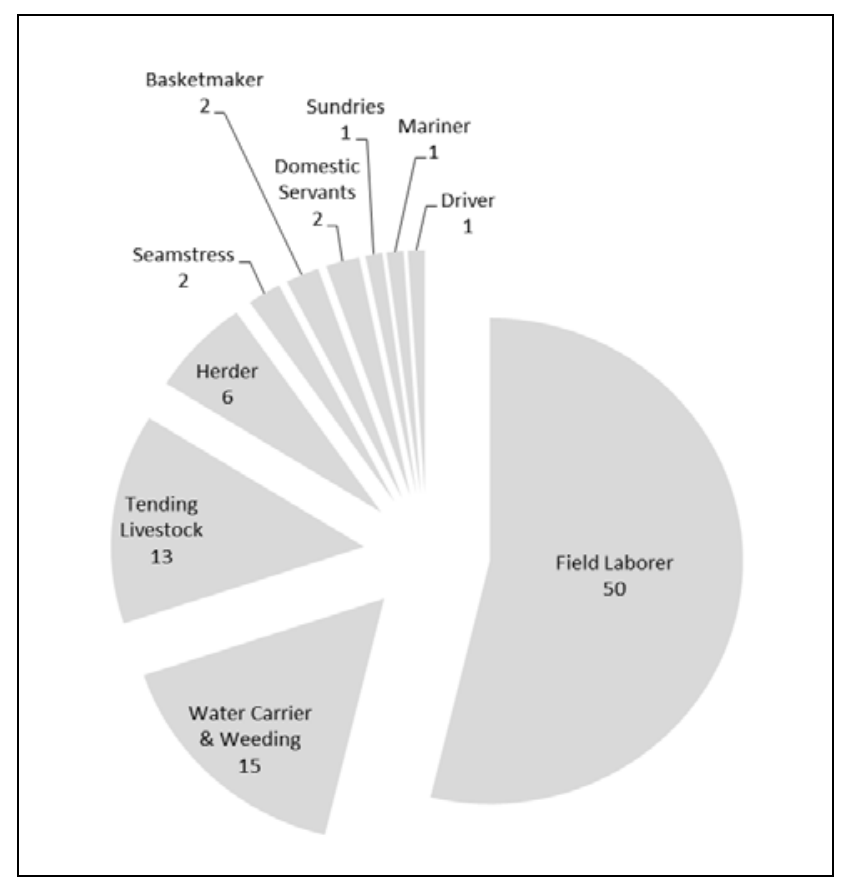

Figure 3. Frequency of occupations among the able-bodied, working-age population at Golden Grove, as listed in Joseph Hunter's July 1834 slave registration return $(N=93)$. The ages of the working population ranged from 6 to 73 years.

A few days before Christmas, Joseph Hunter and his daughter, who had been visiting for six months, dined with Henry Micajah Williams to discuss the holiday schedule. Williams, like Hunter, was an attorney and judge (Blue Book, 1838, pp. 104-106). He owned the nearby Newfield plantation, just west of Port Howe, where over 60 slaves resided (Register of Slaves, 1831c). A member of a North Carolina Loyalist family that had settled on Watlings Island (today's San Salvador), Williams journeyed regularly between New Providence, Cat Island, and Watlings on his schooner Traveller (Peggs, 1957, p. 12). In 1831, he was serving as a magistrate on Cat Island. The three parties agreed to grant their slaves the Saturday before Christmas as a holiday, in addition to the customary two days following Christmas. Hunter would later say that he needed corn to be cut on the Wednesday following 
Christmas, so he preferred Saturday as a holiday.

According to Joseph Hunter, his slaves expressed dissatisfaction with this arrangement by proceeding to the fields on Saturday in defiance of his orders. Hunter wanted to distribute the annual Christmas allotment-consisting of two portions of beef, a quart of rum, and a quart of sugar per person, as well as tobacco and pipes-on Saturday, but the slaves refused. They chose, instead, to collect their allowances on Sunday, and only one person came forward to thank him for it. On Monday, most of Henry Williams's slaves visited Golden Grove to socialize and dance. The following day the Hunter slaves travelled to Newfield. Williams hosted a dinner for the Hunters while the slaves fraternized in the quarters. In the course of the day's events, “Black Dick” Deveaux, then 44 years old, approached Williams on the piazza of his octagonal house. Presumably, Dick was appealing to Williams as a magistrate. He said that his work gang still wanted Wednesday as a holiday, seeing that they had worked on Saturday. Dick contended that Hunter "had grown old and did not support him in his ownership.” Williams insisted that the gang work on Wednesday in accordance with Hunter's wishes. Should they not, Williams added, he as magistrate would have the ringleader punished.

On Wednesday morning, Dick Deveaux rang the bell that signified the hour for heading to the fields. Hunter's field hands, however, did not go out. Sam, a 29-year-old herder at Golden Grove, later testified that even though Dick rang the bell, he had threatened the others not to depart for work. Bristol, a 35year-old sloop captain belonging to Mrs. Poitier, corroborated Sam's testimony. Rose, a 30-year-old field laborer on the Hunter estate, cast doubt on it, saying that she "never heard Black Dick tell the people that if he rang the bell, the negroes were not to go to work.” In either case, the Hunter slaves defied their master's orders and boycotted work on Wednesday.

Antagonisms intensified on Thursday. After finding some 40 oranges from two trees scattered on the ground in the morning, Joseph Hunter accused three slaves - 30-yearold Jack, 23-year-old Morris, and 20-year-old William-of stealing the fruit. $\mathrm{He}$ also confronted William's 17-year-old brother, Young Guy. At that point, Dick Deveaux intervened to defend Young Guy, and a heated exchange with Hunter ensued. Rose overheard Dick saying, his "people will not now take a flogging as they have done." Hunter accused Dick of organizing the Wednesday boycott, saying that he would call for Henry Williams to arbitrate. Dick damned Williams, saying that "he did no good for black people," and then he departed. That afternoon, as talk circulated among her own slaves that Dick was testing a gun, Mrs. Poitier sent a letter to Williams. She requested that he come to Golden Grove the next day with two or three trusty servants and his pistols. At night, Dick returned to the main plantation house to report on the amount of corn that had been cut. Once again, he and Hunter entered into a dispute before Dick headed for the quarters. Given the testimony of fellow slaves, some close to Dick were highly agitated by this time. Rose heard Wally, Dick's eldest son, say "let [Hunter] send whom he will for me, if he puts his hands on me I'll blow his brains out.”

Things came to a head on Friday morning, December 30, 1831. Responding to Mrs. Poitier's letter, Henry Williams arrived at Golden Grove with three servants and two pistols in hand. An 1826 law stipulated that slaves could not bear firearms without permission (Craton \& Saunders, 1992, p. 230), so Williams and Hunter searched the slave houses. Harry, the 68-year-old grandfather of William and Young Guy surrendered a single flintlock musket, 
described by Williams as a gun "to kill game with.” Around 9:30 am, Dick Deveaux and several others passed by Mrs. Poitier on their way to the fields, and a testy exchange of words transpired. Ninety minutes later, Dick returned, leading the whole of his work gang, save for five or six people, out of the fields and into Golden Grove's main yard. Williams testified that the gang amounted to 40-50 men and women. The 1831 and 1834 slave registers, listing at least 44 people (older than 13 years) tasked with field labor at Golden Grove, support Williams's estimate. Dick and his sons, Wally and Richard, had armed themselves with muskets. The other field hands wielded clubs and cutlasses, and according to a fellow slave, they were in a "great deal of wrath." Rose described the clubs as "good middling sized sticks-one could knock down a person.” All the men except Dick, according to Williams's recollections, were stripped bare to the waist with their torsos glistening. The women wore shifts and petticoats.

As they assembled in the yard, their master called out to the driver and demanded that he surrender his weapon. Dick Deveaux ignored him. Henry Williams then repeated the command. Once again, Dick refused, and the entire gang began to move quickly toward the slave houses, "throwing their arms about in defiance,” as Williams later described. Williams, Hunter, and several servants pursued Dick's gang to the yard of the slave houses. Mary Anne Slater Gallagher, a white employee of Mrs. Poitier, came down from the piazza of Hunter's house and followed behind. Upon reaching the yard gate, Williams sent Galvo, one of his trusted slaves, to reason with Dick. As Galvo approached, Dick leveled his musket at him, and uproar ensued. Williams reported that "the men and women set up such a yell as he had never heard before on any plantation." In consequence of the tumult, Galvo retreated.
Hunter now armed himself with one of Williams's pistols. He approached Dick, who leveled the musket at his master three times as a warning to stay back. On the third occasion, Hunter fired at Dick and missed. Williams would claim that it was a warning shot, though Hunter himself was silent on this point. Dick returned fire and then fled the scene by bounding over a stone wall in the midst of another raucous outburst from the gang. In the confusion Wally was heard saying that "he would never do another stroke of work on that plantation, and he defied them to make him.” Bristol, the sloop captain, claimed that Hunter threw a small stone at Linda, a 30-year-old mulatto field laborer. Charlotte, the 35-year-old mother of William and Young Guy, took up a stone to throw at Hunter. Henry Williams then aimed his pistol at her, saying that he would fire on anyone who should strike Hunter. Hunter and Williams withdrew from the slave yard and returned to Hunter's house.

Two slaves were wounded in the crossfire. Jack, who had been accused of stealing oranges, was hit above the waistband, presumably with shot from Dick Deveaux's musket. One of Dick's daughters was also wounded in the arm. Neither casualty was fatal. Over the next three days and nights, Golden Grove remained unsettled. Joseph Hunter, with the assistance of some dutiful servants, kept watch at his house as preparations were made for a departure to Nassau. That departure, likely on the schooner Traveller, apparently occurred on Tuesday, January 3, 1832.

\section{The King vs. Black Dick}

On Wednesday afternoon, the Royal Gazette (1832a) broke news of the upheaval:

We stop the press to say, that we just now heard of an insurrection of several Negroes on the plantation of the Honorable Joseph Hunter ... We are requested to state that 
the present is merely a renewal of like occurrence on the same plantation, two or three years ago ...

A military force from the Second West India Regiment under the command of Lt. Hookey sailed for Cat Island aboard the HMS Kangaroo. On Friday, January 13, Lt. Hookey returned to Nassau, having apprehended Dick Deveaux, seven other men, and two women (Royal Gazette, 1832b). This group was imprisoned at the jail, and eleven days later, a bill of indictment was returned in the General Court. The Bahama Argus (1832b) publicized it as "The King vs. Black Dick, otherwise called Dick Deveaux, and others-Felony." The indictment of Dick Deveaux included a charge of attempted murder, as well as two counts of what today would be called aggravated assault: shooting with intent to disable Mr. Hunter and shooting with intent to do "grievous bodily harm." The other prisoners were charged in each of the three counts with using "force and arms" in the felonious acts of "aiding, abetting, and assisting” (General Court, 1832). These included Dick's sons, Wally and Richard, along with Jack (who had been wounded), Morris, William, Young Guy, and Will Deveaux. Charlotte and Linda, who had faced-off with Hunter and Williams, were also charged as accomplices.

The trial of Dick Deveaux and his alleged abettors occurred on Wednesday, January 25 from 10:00 am until 9:00 pm (Bahama Argus, 1832b). Nine depositions were taken, including those of Joseph Hunter, Henry Williams, Sarah Anne Poitier, Mary Anne Slater Gallagher, and William Pennycook, assistant surgeon aboard the Kangaroo. In addition, four slaves testified: Sam Hunter, Rose Hunter, Bristol Poitier, and Will Deveaux. After twenty minutes of deliberation, verdicts were rendered. The Court acquitted Charlotte and Linda, and it acquitted Will Deveaux when it became clear that he was absent during the critical events. In contrast, the Court found Dick Deveaux and the other six men guilty. A death sentence was passed on each of these seven, and public hangings were scheduled to take place after a fortnight.

Governor Smyth harbored abolitionist sympathies (Saunders, 1985, p. 176). After reviewing the case he found cause to intervene. He issued pardons for the six who were convicted as accessories, sparing them from the gallows. He allowed the execution of Dick Deveaux, however, to proceed, and the sentence was realized before a modest crowd on the morning of February 8, 1832. The Royal Gazette (1832c) opined that Dick "had been sensible of his crime, acknowledged the justice of his sentence, and hoped for mercy in another world." Smyth issued a statement intended for circulation throughout all the islands. While reminding slaves of the governor's commitment to preventing slaveholder cruelty, it reiterated the government's intention to quell "tumultuous meetings” (Royal Gazette, 1832d). Smyth hoped that the execution would serve as a warning against possible future unrest.

The next six months saw Smyth attempt to substantiate his actions before F. J. Robinson, the Viscount Goderich, who was Colonial Secretary in London and a former British Prime Minister. In a March letter to Goderich, Smyth (CO23/86/52-55) contended that it was a "rather harsh measure" for Joseph Hunter to deny slaves the Wednesday holiday, and that the Hunter slaves had reason to be aggrieved. Smyth added that "the excitement and angry feelings caused by ... withholding [Wednesday as a holiday] and not any premeditated scheme of insurrection or determination to resist the lawful authority of their Master led to the tumult and riot which took place."

Goderich (CO23/86/52-55), responding in 
June, agreed that the denial of Wednesday as a holiday was harsh. He was, however, unmoved by most of Smyth's portrayal of the event, and he refused to approve Smyth's intervention. With the court transcript at his disposal, Goderich plainly revealed the Golden Grove uprising to be a premeditated revolt worthy of "serious and just alarm." The slaves, Goderich offered, took Wednesday in open defiance of both the master's and the magistrate's authority. The armed gang's abandonment of work at an unusual hour and their forcible resistance did not occur until Friday, two days after the end of the holidays. Moreover, the men being stripped to the waist confirmed that the slaves acted in concert. In a lengthy August reply, Smyth (1832b) made no attempt to contest Goderich's points. Instead, he argued that the pardons were calculated to preserve the peace and avoid additional uprisings. He described the weak presence of state authority on Cat Island where slaves were not governed by strong displays of physical force. "A chain of such feeble links," Smyth argued, "must not be strained.”

\section{The Uprising's Counter-Narrative}

Caution, of course, must be exercised with interpretation of court transcripts and newspaper commentaries that were created by, and for, white colonial elites. Testimonies of Bahamian planters were influenced by prevailing views about the inferiority and "natural moral turpitude" of African-descent peoples (Bahama Argus, 1832c; Craton, 1979, p. 113). Court secretaries who shared the planters' worldview filtered the testimonies of illiterate slaves. It is thus all the more telling that the only mention of flogging at Golden Grove during the court proceedings came from Rose, one of Joseph Hunter's field slaves. None of the whites who testified ever alluded to the existence of corporal punishment on the plantation, nevermind its potential to aggravate insubordination. Doing so would have introduced mitigating circumstances that might have augmented sympathies for the slaves on trial, at least among the more progressive British colonials who favored improvement of slave conditions. Yet while individuals such as Rose could present legal testimony under an 1826 slave act, slaves still could not testify against their masters (Saunders, 1985, p. 178). Consequently, Rose's reference to flagellation was carefully qualified. The end of her deposition stated that "Master does not like flogging - he curses you, works you hard, but he does not like flogging. He won't flog often. You must do a great fault to be flogged ... There is not much flogging on the estate.” In this light, Rose's testimony dovetailed with that of Mary Anne Slater Gallagher, who deemed Joseph Hunter a "very humane Master, too much so.”

Given that the accused were not permitted to testify in their own defense, it is worth considering how else Hunter's slave community may have perceived the need for action against their master. Some insight can be gleaned from a letter to the editor of the Bahama Argus (1832d) published three and a half weeks after Dick Deveaux's execution. Ostensibly, the letter criticized Governor Smyth for neglecting to circulate a June 1831 proclamation from King William IV that reaffirmed the institution of slavery. The writer added that, had there been greater efforts to publicize the proclamation, perhaps "Mr. Hunter's gang would not have rebelled against him.” The Hunter slaves, according to the author, were "excited to a high degree ... regarding their being made free on last NewYear's day.”

The belief among slaves that emancipation was imminent, or that it was already being withheld by local elites, was a pervasive one in the West Indies from at least 1790 (Craton, 1982, p. 244). It was fueled by the campaign of British abolitionists to end the institution of slavery; the first success of this campaign was 
the Slave Trade Act of 1807 which abolished the trans-Atlantic trade in African captives (Hochschild, 2005). This movement intensified after the London-based AntiSlavery Society launched a lobbying effort in 1823 that would ultimately lead to emancipation for slaves throughout the British Empire. Resolutions from the House of Commons that called for the "amelioration," or improvement, of slave conditions were sent to the colonies (Canning, 1824).

In response, the Bahamian Assembly passed Consolidated Slave Acts in 1824, 1826, and 1830, together with supplementary and amending acts. These laws, which came to be known as the Amelioration Acts (Craton \& Saunders, 1992, pp. 229-231; W. B. Johnson, 1996), mandated Christian teaching and limited family separation; children under the age of 14, for example, could not be legally removed from their mothers. The laws restricted corporal punishment, such as prohibiting the flogging of females in the company of males except their owners. They gave slaves a legal exemption from labor on Sundays, as well as the right to possess personal property apart from firearms, ammunition, and other slaves. The 1826 Act allowed certain slaves-baptized creoles with five years of residence in the colony-to offer limited testimony in specific types of court cases. Slaves still could not, however, testify in cases where a slaveholder had been indicted. Moreover, the 1826 Act reformed manumission procedures, making it not only less expensive for a slave to be set free, but also legal under certain conditions for slaves to buy their own freedom. The reforms, according to Craton and Saunders (1992, p. 231), "suddenly increased the number of freed coloreds and blacks." In cases such as the exemption from work on Sundays and some aspects of property ownership, the Amelioration Acts simply formalized what were already customary practices. In other cases, such as the right to testify in court, the new statutes gave slaves the semblance of civil liberties enjoyed by people of colour who were already free. The manumission reform quite literally helped to expand the ranks of freedmen. In light of these circumstances, Craton (1979, p. 113) has argued that the salutary effect of the Amelioration Acts was exaggerated for many slaves, who saw them as immediate forerunners to complete emancipation.

A narrative involving the denial of emancipatory rights was not unique to the Golden Grove uprising. It was cited in nearly every slave insurrection of the early nineteenth century, including Pompey's Revolt on Exuma in 1830 and the Jamaica Rebellion of 1831-1832 that became known as the "Baptist War" (Craton, 1983, p. 27; Saunders, 1985, p. 185). News of the Jamaican conflict was being reported in the Nassau newspapers at the same time as the events of the Golden Grove uprising were unfolding. On the day of Dick Deveaux's trial, the Bahama Argus (1832a) offered an account of events in Jamaica:

Great numbers of those slaves, who had been informed by evil disposed persons, that at Christmas they would all be set free, and who, consequently, not finding it to be the case, rebelled against their masters, have returned quietly to their work. A great many, however, have been shot.

Although emancipation was not legally enacted until 1834, the belief that it had come about earlier through legislation or Royal Proclamation was apparently no less real in the minds of Hunter's slaves. There were legitimate reasons to embrace the ideology, given discourses about freedom that found their way to Cat Island through the activities of local slaveholders. Henry Williams, for example, voiced concern as early as 1823 that emancipation was close at hand. He was one 
of several planters to protest the British Parliament's resolutions on the amelioration of slave conditions. He co-signed a Bahamian response that expressed anxiety over the possibility that Parliament would soon consider a proposal for the "total extinction of slavery" (An Official Letter from the Commissioners of Correspondence, 1823). By the summer of 1831, news of ongoing emancipation debates in London sparked widespread hearsay that all slaves would be free after the Christmas holidays (Craton, 1979, p. 109).

In the end, both the planter's narrative, which emphasized slave discontentment with the precise start of the Christmas holidays, and the counter-narrative of freedom's suppression were likely both true in the minds of their beholders. No matter which narrative one chooses to emphasize today, both represented the slaves' repudiation of conditions set by their master, as noted by Craton (1979, p. 124).

\section{The Aftermath}

Joseph Hunter exacted retribution on Richard, Dick Deveaux's pardoned son, by selling him to a Mr. Kemp of New Providence just before Dick's execution (Register of Slaves, 1834b). The other defendants ultimately returned to Golden Grove where they remained as field laborers until emancipation. During the transitional period known as apprenticeship (1834-1838), these former slaves became nominally free but were still tied to the estate. Near the second anniversary of emancipation, Hunter considered establishing a school on his estate for the children of his apprentices (Bahama Argus, 1836), but whether such a school ever materialized is not known.

Just as Richard was punished for treachery, another was rewarded for loyalty. Sam, who among the three Hunter slaves to testify was most unwavering in implicating Dick Deveaux, became Golden Grove’s head driver
(Register of Slaves, 1834a). Perhaps this is why, decades after emancipation, an Anglican priest found an elderly Sam Hunter at Lucky Mount waxing nostalgic about life in the slavery days. The observer, himself an apologist for slavery, claimed that as death approached, "Daddy Sam" was "telling everyone that he was going to see his old owner Hunter, whom he seemed to cherish in loving memory” (Matthews, 1998, p. 5). Sam Hunter had somehow gained legal possession of the Lucky Mount property after emancipation, and he willed 400 acres of this land to his children before dying in 1886 (Supreme Court Wills, 1879).

In the years following the uprising, Joseph Hunter rose to new political heights. He became president of the Executive Council by 1835 and also served as the colony's interim governor in 1837 (Blue Book, 1838, pp. 5859; Great Britain Foreign Office, 1838, pp. 134-135). His daughter, Sarah Anne, continued to deal with slave resistance, posting an advertisement in summer 1832 for a runaway slave named Caesar who had fled her estate on New Providence (Royal Gazette, 1832e). Her two sons would enter the ranks of the British Army (Hart, 1846), and her daughter, Elizabeth Alicia, would marry the grandson of Lord Dunmore before moving to Australia and then to England. Joseph Hunter's son, Hugh Edward Hunter, died in 1837 after rising in the military to the rank of colonel (Supreme Court Wills, 1838). Mrs. Poitier succumbed the following year, and her father followed suit on July 13, 1838, a little more than two weeks before the apprenticeship period ended. Hence, the Hunter family deaths are closely aligned with the ultimate demise of Bahamian slavery. To date, no evidence suggests that surviving family members ever returned to Golden Grove. Ex-slaves of the Hunter plantation eventually claimed the tract as "generation 
land” (Craton, 1987). Their descendants farm portions of it to this day.

\section{CONCLUSIONS}

Previous historical treatments have underestimated the extent of the Golden Grove uprising (Craton \& Saunders, 1992; Johnson, 2000; Saunders, 1985). The episode involved more people, a more coordinated effort, and a more serious challenge to their owner and the local magistrate's authority than has been previously acknowledged. It was not simply an inter-personal dispute (Johnson, 2000, pp. 165-166). As Viscount Goderich (CO23/86/52-55) deduced, it was a premeditated insurrection warranting "serious and just alarm" on the part of the colonial government. Seeing the uprising in this new light underscores several themes that have emerged in the study of early nineteenthcentury slavery in the British West Indies. First, resistance in its varying forms was pervasive in slave society, even before the early 19th century. The Royal Gazette (1832a) newspaper hinted that Hunter's estate had witnessed slave unrest in the years before the 1831 uprising, never mind the daily forms of resistance found there. Second, the gathering momentum of anti-slavery ideas-starting with events leading to the Slave Trade Act of 1807, which abolished this trade, and continuing with the Amelioration Acts of 1824, 1826, and 1830 - strongly influenced slaves who saw these enactments as harbingers of emancipation (Craton, 1979, pp. 113-118). Third, slaves holding positions of responsibility played crucial roles in mobilizing larger groups to act against the established system of slavery (Craton, 1982, pp. 54-55). The central catalysts at Golden Grove in 1831 were the driver and his two sons. During that episode, Dick Deveaux defended fellow slaves who had been accused of stealing, and he defied the possibility of corporal punishment. His sons supported him as antagonisms flared. Lastly, insurgent strategies emphasized labor strikes and boycotts to thwart slaveholders, rather than an overthrow of the entire system of enslavement (Craton, 1979, pp. 113-118). The Golden Grove uprising involved the collective refusal by slaves to participate in plantation activities as scheduled by the master. This included two distinct labor strikes in the week following Christmas, one on Wednesday and another on Friday that culminated in armed confrontation.

The downplaying of vivid episodes of slave resistance such as the Golden Grove uprising has important implications for contemporary political discourse. In a provocative 2011 article for the Nassau Guardian titled "Bahamians Have a Slave Mentality," Dehaviland Moss argues that modern Bahamians are less apt to protest inequalities because the treatment of their enslaved ancestors was relatively benign. "Bahamians by heart" Moss (2011) contends, "are not a fighting people when it comes to challenging the 'master" (however "master" might be defined in the modern world). This disposition among so many Bahamians, Moss asserts, is rooted in generations of experience extending back to the pre-emancipation era when "slaves accepted their master as a good person and viewed him favorably." Such an argument is infused with irony because to make it, one must internalize the propaganda of white, slave-owning planters who defended the institution of slavery by claiming they were benevolent masters of contented slaves with lives of relative ease (Stephen, 1824, pp. 459-461). The historical record, however, is rife with examples of slave unrest. Between 1784 and 1834, over 450 runaway slave ads appeared in Nassau newspapers, exposing the myth that Bahamian slavery was essentially harmless and that the enslaved were resigned to it (Craton, 1993, pp. 275, 281; Craton \& Saunders, 1990, p. 5).

Moss's portrayal of modern Bahamians as less 
inclined to protest social inequality may not be the most accurate. If, on the other hand, it contains an element of truth, then the argument should emphasize how today's Bahamians have turned away from a long and storied tradition of protest, born in the archipelago's slave fields and exemplified by the likes of Pompey's Revolt, the Golden Grove uprising, and the 1833 Johnson Estate insurrection at Eleuthera (Saunders, 1984).
Rather than discarding "slave mentality," as Moss proposes, Bahamians would do well to rediscover elements of the kind of slave ideology that contested inequality and subverted injustice. In doing so, the name of Dick Deveaux, who sought dignity through resistance, might one day be elevated to the status of Pompey as a hero of Bahamian selfdetermination.

\section{REFERENCES}

An official letter from the Commissioners of Correspondence, of the Bahama Islands, to George Chalmers, Esq., Colonial Agent concerning the proposed abolition of slavery in the West Indies. (1823). Liverpool, England: S. H. Hankey.

Bahama Argus. (1832a, January 25). Account of the Jamaica rebellion. Bahama Argus, p. 2.

Bahama Argus. (1832b, January 28). General Court. Bahama Argus, p. 2.

Bahama Argus. (1832c, March 3). Lt. Hookey's return from St. Salvador. Bahama Argus, p. 2.

Bahama Argus. (1832d, March 3). Letter to the editor. Bahama Argus, p. 2.

Bahama Argus. (1836, July 23). [Excerpt from Bahama Argus on proposed schools at Cat Island]. Colonial Office Records (CO23/97/163). Department of Archives, Nassau, Bahamas.

Bahama Gazette. (1815, January 15). Death notice-Andrew Deveaux. Bahama Gazette, p. 3.

Bahama Records. (1801). Indenture between Joseph Hunter, John Russell, and Miles McInnes (Book I2, Folios 420-433). Department of Archives, Nassau, Bahamas.
Bahama Records. (1808). Joseph Hunter's title of 400 acres at Saint Salvador (Book K23, Folio 23). Department of Archives, Nassau, Bahamas.

Blue Book of Statistics. (1834). Record of the Colonial Secretary's Office. Department of Archives, Nassau, Bahamas.

Blue Book of Statistics. (1838). Record of the Colonial Secretary's Office. Department of Archives, Nassau, Bahamas.

Brown, S. L. (1992). 'This is the real Bahamas': Solidarity and identity in Cat Island. (Unpublished doctoral dissertation). University of California-San Diego, San Diego.

Canning, G. (1824). Speech of the Right Hon. George Canning, Secretary of State for Foreign Affairs, \&c. \&c. \&c. on laying before the House of Commons the papers in explanation of the measures adopted by His Majesty's government with a view of ameliorating the condition of the negro slaves in the West Indies, on Wednesday, the 17th of March, 1824. London, England: L. Relfe. Retrieved from https://books.google.bs/books?id=vF0SAA AAIAAJ

Craton, M. (1979). Proto-peasant revolts? The late slave rebellions in the British West Indies 1816-1832. Past \& Present, 85, 99- 
125. Retrieved from

http://www.jstor.org/stable/650681

Craton, M. (1982). Testing the chains:

Resistance to slavery in the British West

Indies. Ithaca, NY: Cornell University

Press.

Craton, M. (1983). We shall not be moved: Pompey's slave revolt in Exuma Island, Bahamas, 1830. New West Indian Guide, 57, 19-35. Retrieved from http://www.jstor.org/stable/41849104

Craton, M. (1987). White law and black custom: The evolution of Bahamian land tenures. In J. Besson \& J. Momsen (Eds.) Land and development in the Caribbean (pp. 88-113). London, England: Macmillan Caribbean.

Craton, M. (1993). Hope Town and Hard Bargain: The Loyalist transformation in the Bahamas. In R. Bennett (Ed.) Settlements in the Americas: Cross-cultural perspectives (pp. 255-282). Newark: University of Delaware Press.

Craton, M., \& Saunders, D. G. (1990). Seeking a life of their own: Aspects of slave resistance in the Bahamas. Journal of Caribbean History, 24, 1-27.

Craton, M., \& Saunders, G. (1992). Islanders in the stream: A history of the Bahamian people (Vol. 1). Athens: University of Georgia Press.

Estate Appraisals and Indentures. (1815). Inventory and appraisement of the estate of Andrew Deveaux, senior, Registrar General Office (Book Z2, 1806-1818). Department of Archives, Nassau, Bahamas.

Estate Appraisals and Indentures. (1838). Inventory and appraisement of the estate of Joseph Hunter, Registrar General Office (1838-1853). Department of Archives, Nassau, Bahamas.
General Court of the Bahamas. (1832). [Minutes of the trial of Dick Deveaux and others, the property of Joseph Hunter]. Colonial Office Records (CO23/86/56-68). Department of Archives, Nassau, Bahamas.

Goderich, Viscount. (1832, June 4). [Letter from Goderich to Smyth]. Colonial Office Records (CO23/86/52-55). Department of Archives, Nassau, Bahamas.

Great Britain. Foreign Office. (1838). Correspondence with the British commissioners relating to the slave trade, 1837. London, England: W. Clowes and Sons. Retrieved from https://books.google.bs/books?id=PnFbAA AAQAAJ

Hart, H. G. (1846). The new annual army list, for 1846. London, England: J. Murray. Retrieved from https://ia902703.us.archive.org/28/items/ha rtsannualarmy01hartgoog/hartsannualarmy 01hartgoog.pdf

Hochschild, A. (2005). Bury the chains: Prophets and rebels in the fight to free an empire's slaves. Boston, MA: Houghton Mifflin.

Lands Grants. (1810). [Index entry of an 1806 survey of Joseph Hunter's property at St. Salvador] (Book K, 1803-1810, Entry 23). Department of Archives, Nassau, Bahamas.

Land Grants. (1813). [Index entry of Joseph Hunter's property at Grand Bahama] (Book L1, 1812-1850, Entry 51). Department of Archives, Nassau, Bahamas.

Johnson, H. (1996). The Bahamas from slavery to servitude, 1783-1933. Gainesville: University Press of Florida.

Johnson, W. B. (1996). The Amelioration Acts in the Bahamas, 1823-1833. Journal 
of the Bahamas Historical Society, 18, 2132.

Johnson, W. B. (2000). Race relations in the Bahamas, 1784-1834: The nonviolent transformation from a slave to a free society. Fayetteville: University of Arkansas Press.

Lofquist, W. S. (2010). Identifying the condemned: Reconstructing and analyzing the history of executions in The Bahamas. International Journal of Bahamian Studies, 16, 19-34. Retrieved from http://dx.doi.org/10.15362/ijbs.v16i0.125

Matthews, F. B. (1998). San Salvador described, 1885-1889. Nassau, Bahamas: Department of Archives.

Moss, D. (2011, July 20). Bahamians have a slave mentality. Nassau Guardian.

Retrieved from http://www.thenassauguardian.com/index.p hp?option=com_content\&id=11690:baham ians-have-a-slave-mentality\&Itemid=86

Peggs, A. D. (1957). A relic of slavery: Farquharson's journal for 1831-32. Nassau, Bahamas: Deans Peggs Research Fund.

Register of Slaves. (1831a). Return of the estate of Charles Poitier (Entry 779). Department of Archives, Nassau, Bahamas.

Register of Slaves. (1831b). Return of the estates of Charles Poitier and Joseph George Hunter (Entry 759). Department of Archives, Nassau, Bahamas.

Register of Slaves. (1831c). Return of Henry M. Williams (Entry 1133). Department of Archives, Nassau, Bahamas.

Register of Slaves. (1831d). Return of Joseph Hunter (Entry 427). Department of Archives, Nassau, Bahamas.
Register of Slaves. (1834a). Return of Joseph Hunter (Entry 463). Department of Archives, Nassau, Bahamas.

Register of Slaves. (1834b). Schedule of slaves not included in the return of Joseph Hunter (Entry 464). Department of Archives, Nassau, Bahamas.

Royal Gazette. (1808a, October 19). Marriage announcement for Charles Poitier and Sarah Ann Hunter. Royal Gazette and Bahama Advertiser, p. 3.

Royal Gazette. (1808b, November 23). Wants a situation. Royal Gazette and Bahama Advertiser, p. 3.

Royal Gazette. (1832a, January 4). Postscript. Royal Gazette and Bahama Advertiser, p. 3.

Royal Gazette. (1832b, January 14). Nassau. Royal Gazette and Bahama Advertiser, p. 3.

Royal Gazette. (1832c, February 11). Nassau. Royal Gazette and Bahama Advertiser, p. 2.

Royal Gazette. (1832d, February 15). Government notice. Royal Gazette and Bahama Advertiser, p. 1.

Royal Gazette. (1832e, June 27). Runaway slave advertisement. Royal Gazette and Bahama Advertiser, p. 3.

Saunders, D. G. (1978). The slave population of the Bahamas, 1783-1834 (Unpublished master's thesis). University of the West Indies, Kingston, Jamaica.

Saunders, D. G. (1984). Slave resistance in the Bahamas. Journal of the Bahamas Historical Society, 6, 25-29.

Saunders, D. G. (1985). Slavery in the Bahamas, 1648-1838. Nassau, Bahamas: Nassau Guardian.

Saunders, G. (2002). Slavery and cotton culture in the Bahamas. In V. Shepherd 
(Ed.). Slavery without sugar: Diversity in Caribbean economy and society since the 17th century (pp. 129-151). Gainesville: University Press of Florida.

Smyth, J. C. (1832a, March 6). [Letter from Smyth to Goderich]. Colonial Office Records (CO23/86/50-50). Department of Archives, Nassau, Bahamas.

Smyth, J. C. (1832b, August 9). [Letter from Smyth to Goderich]. Colonial Office Records (CO23/86/345-350). Department of Archives, Nassau, Bahamas.
Stephen, J. (1824). The slavery of the British West Indies delineated (Vol. 1). London, England: J. Butterworth and Son.

Supreme Court Wills. (1822). Last will and testament of Charles L. Poitier. Department of Archives, Nassau, Bahamas.

Supreme Court Wills. (1838). Last will and testament of Sarah Anne Poitier. Department of Archives, Nassau, Bahamas.

Supreme Court Wills. (1879). Last will and testament of Samuel Hunter. Department of Archives, Nassau, Bahamas. 